\title{
Serious BTEX pollution in rural area of the North China Plain during winter season
}

\author{
Kankan Liu, Chenglong Zhang, Ye Cheng, Chengtang Liu, Hongxing Zhang, Gen Zhang, \\ $\mathrm{Xu}$ Sun, Yujing $\mathrm{Mu}^{*}$
}

Research Center for Eco-Environmental Sciences, Chinese Academy of Sciences, Beijing 100085, China

\section{A R T I C L E I N F O}

Article history:

Received 25 April 2014

Revised 30 May 2014

Accepted 30 May 2014

Available online 29 January 2015

\section{Keywords:}

BTEX

Rural area

Coal combustion

\begin{abstract}
A B S T R A C T
Atmospheric BTEX compounds (benzene, toluene, ethylbenzene and xylenes) in a rural site of the North China Plain (NCP) were preliminarily investigated in winter, and the outdoor concentrations $\left(25.8-236.0 \mu \mathrm{g} / \mathrm{m}^{3}\right)$ were found to be much higher than those reported in urban regions. The pollution of BTEX inside a farmer's house was even more serious, with combined concentrations of $254.5-1552.9 \mu \mathrm{g} / \mathrm{m}^{3}$. Based on the ratio of benzene to toluene $(1.17 \pm 0.34)$ measured, the serious BTEX pollution in the rural site was mainly ascribed to domestic coal combustion for heating during the winter season. With the enhancement of farmers' incomes in recent years, coal consumption by farmers in the NCP is rapidly increasing to keep their houses warm, and hence the serious air pollution in rural areas of the NCP during winter, including BTEX, should be paid great attention.
\end{abstract}

(C) 2015 The Research Center for Eco-Environmental Sciences, Chinese Academy of Sciences. Published by Elsevier B.V.

\section{Introduction}

Atmospheric BTEX compounds (benzene, toluene, ethylbenzene and xylenes), mainly emitted from various anthropogenic activities (Buczynska et al., 2009), have already aroused concern due to their adverse health effects (Aksoy, 1989; Dutta et al., 2009) and their roles in atmospheric chemistry (Barletta et al., 2008). The ambient levels of both indoor (Zhong et al., 2005; Guo et al., 2003) and outdoor BTEX in cities (Yuan et al., 2010; Wang et al., 2012; Li et al., 2014: Zhang et al., 2012) have been extensively investigated. However, the levels in rural areas have only rarely been reported (Guo et al., 2006). With the enhancement of farmers' incomes in recent years, the amount of coal combustion is rapidly increasing to keep their houses warm and comfortable during the cold winter season in the North China Plain (NCP). A large quantity of pollutants including BTEX is emitted by domestic coal combustion due to low combustion efficiency, and hence high levels of pollutants were suspected in the rural area of the NCP with high-density dwellings in winter.

In this work, the ambient levels of BTEX in a rural site of the NCP during wintertime were preliminarily investigated and compared with those reported in Chinese cities. In addition, the risk to farmers' health was also roughly estimated.

\section{Materials and methods}

\subsection{Sampling sites}

Outdoor air samples were collected at a sampling site in a rural agricultural field $\left(38^{\circ} 40^{\prime} \mathrm{N}, 115^{\circ} 15^{\prime} \mathrm{E}\right)$ in Wangdu County, Hebei Province, which is $\sim 200 \mathrm{~km}$ southwest of Beijing city, about $120 \mathrm{~km}$ northeast of Shijiazhuang city, $35 \mathrm{~km}$ southwest of Baoding city, and $10 \mathrm{~km}$ east of Wangdu County. The nearest village of Dongbaituo (DBT) is about $200 \mathrm{~m}$ away to the west of the sampling site. There are almost no industries in Wangdu County, and pollutant emissions were mainly from coal combustion for cooking and warming during the winter season. Indoor air samples were collected in a farmer's house of the village of DBT.

\subsection{Sampling and analysis}

Air samples were collected with a 100-mL syringe and immediately transferred into an absorption tube (15 cm length, $4 \mathrm{~mm} \mathrm{ID)}$

\footnotetext{
* Corresponding author. E-mail: yjmu@rcees.ac.cn (Yujing Mu).
} 
filled with Tenax-TA (80-100 mesh, $100 \mathrm{mg}$, Alltech Associates, Inc. America). A total of 49 outdoor air samples were collected hourly from 7:00 to 21:00 during 23 to 27 January in 2013, and 31 indoor air samples were collected in the morning, noon, and evening during the same period. The absorption tube was connected to a six-port valve as a loop and BTEX enriched in the absorption tube were injected into a separation column (SE-30, $20 \mathrm{~m} \times 0.53 \mathrm{~mm} \times 1.0 \mu \mathrm{m}$ ), after heating for $40 \mathrm{sec}$ in an oven kept at $300^{\circ} \mathrm{C}$, and detected by a gas chromatograph equipped with a Photo Ionization Detector (GC-PID, GC4400, East \&West Analytical Instruments, Inc., China) with $\mathrm{N}_{2}$ as carrier gas. The details on the preparation of the absorption tube as well as sampling and analysis procedures have been described in our previous publications (Liu et al., 2009, 2013; Zhang et al., 2012). The collection efficiencies for benzene, toluene, ethylbenzene, m,p-xylene and o-xylene were $84.2 \%, 95.6 \%, 96.4 \%, 96.1 \%$ and $95.5 \%$, respectively. The method detection limits (with a signal-to-noise ratio of 3) were 0.01, 0.02, 0.06, 0.07 and $0.07 \mu \mathrm{g} /$ $\mathrm{m}^{3}$, respectively.

\section{Results and discussion}

\subsection{Ambient levels and variation characteristics}

Fig. 1 shows the time series of outdoor ambient levels of each BTEX compound and wind speed during the sampling days. The total concentrations of BTEX compounds during the sampling days varied remarkably, from ca. 30 to $230 \mu \mathrm{g} / \mathrm{m}^{3}$, which was mainly ascribed to the variation in meteorological conditions. Among various meteorological conditions, wind speed is the most efficient factor for accelerating diffusion of pollutants, e.g., a sharp decrease of BTEX concentrations was observed in the afternoon on 24, 26-27 January when wind speed increased. Although the wind speed (the maximum was near $5 \mathrm{~m} / \mathrm{sec}$ ) was the fastest on 25 January, the BTEX concentrations were much higher than those on the day of 26 January when wind speed was less than $2 \mathrm{~m} / \mathrm{sec}$, indicating that the concentrations of BTEX near the earth's surface were also controlled by other factors besides wind speed. The boundary height has been found to dominate primary pollutant accumulation (Quan et al., 2013), and the relatively low BTEX concentrations in the afternoon on 26 January were suspected to be due to the fast elevation of the boundary layer. On the other hand, warmer weather is usually coincident with low wind speed, and hence coal consumption for heating by farmers might be less on warmer winter days with low wind speed than on the colder winter days with high wind speed.

\subsection{Comparison with previous studies}

The average concentrations of BTEX compounds investigated by this study were compared with others reported in China, and listed in Table 1. It is evident that the outdoor concentrations of BTEX compounds $\left(25.8-236.0 \mu \mathrm{g} / \mathrm{m}^{3}\right)$ in this study were at least a factor of 3 higher than those reported in Chinese cities or rural areas (Zhong et al., 2005; Guo et al., 2003, 2006; Wang et al., 2008; Wang and Zhao, 2008; Ling et al., 2011; Zhang et al., 2012; Li et al., 2014), indicating that the pollution levels of BTEX in this rural area of the NCP are indeed very serious in winter. The indoor pollution levels of BTEX $\left(254.5-1552.9 \mu \mathrm{g} / \mathrm{m}^{3}\right)$ were found to be more serious, a factor of 1.26 higher than the outdoor levels. It should be mentioned that the farmer's house adopted for collecting the indoor air samples was well ventilated by keeping a fan running in the kitchen where the coal stove was used for heating and cooking. Even more serious BTEX pollution was suspected in most farmers' houses without a fan for ventilation.

In addition, outdoor levels of $\mathrm{PM}_{2.5}$ and $\mathrm{SO}_{2}$ in $\mathrm{DBT}$ and Beijing were also synchronously measured and the data are illustrated in Fig. 2. It is evident that the levels of $\mathrm{PM}_{2.5}$ and $\mathrm{SO}_{2}$ in $\mathrm{DBT}$ during most sampling days were remarkably greater than those in Beijing city, further indicating that the air pollution in the rural area in winter was very serious.

\subsection{Sources identification}

The ratio of benzene to toluene $(\mathrm{B} / \mathrm{T})$ is usually used as an indicator to identify their sources' origination because different $\mathrm{B} /$ $\mathrm{T}$ ratios are characteristic of different sources. A B/T ratio of around 0.6 has been reported to be characteristic of vehicular emissions (Perry and Gee, 1995; Brocco et al., 1997; Barletta et al.,

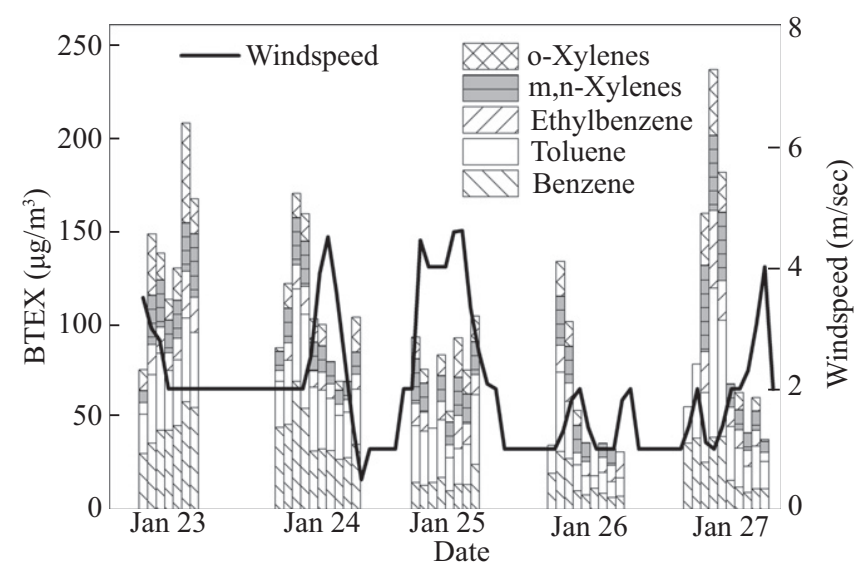

Fig. 1 - Concentrations of outdoor BTEX (benzene, toluene, ethylbenzene and xylenes) compounds and wind speed from 23 to 27 January, 2013. 


\begin{tabular}{|c|c|c|c|c|c|c|c|c|}
\hline \multicolumn{2}{|c|}{ Location (sampling time) } & \multirow{2}{*}{$\begin{array}{c}\begin{array}{c}\text { Number of } \\
\text { samples }\end{array} \\
31\end{array}$} & \multirow{2}{*}{$\begin{array}{c}\text { Benzen } \\
34.4 \pm 20.4 \\
(10.8-88.7)\end{array}$} & \multirow{2}{*}{$\begin{array}{l}\text { Toluene } \\
58.9 \pm 43.1 \\
(12.9-184.1)\end{array}$} & \multirow{2}{*}{$\begin{array}{c}\text { Ethylbenzene } \\
28.0 \pm 18.7 \\
(5.4-105.8)\end{array}$} & \multirow{2}{*}{$\begin{array}{c}\text { m,p-Xylene } \\
\begin{array}{c}58.1 \pm 42.9 \\
(6.9-177.3)\end{array}\end{array}$} & \multirow{2}{*}{$\begin{array}{c}\text { o-Xylene } \\
30.2 \pm 8.5 \\
(14.9-54.6)\end{array}$} & \multirow{2}{*}{$\begin{array}{l}\text { References } \\
\text { This work }\end{array}$} \\
\hline Indoor & $\begin{array}{l}\text { Dongbaituo, Hebei } \\
(1 / 2013)\end{array}$ & & & & & & & \\
\hline & Hongkong, Home (2001) & 24 & $\begin{array}{l}5.0 \pm 2.6 \\
(1.4-10.3)\end{array}$ & $\begin{array}{l}59.1 \pm 19.8 \\
(29.9-83.1)\end{array}$ & $\begin{array}{c}2.7 \pm 2.2 \\
(0-6.9)\end{array}$ & $\begin{array}{l}5.3 \pm 2.6 \\
(1.4-10.8)\end{array}$ & $\begin{array}{l}3.9 \pm 2.6 \\
(1.0-11.0)\end{array}$ & $\begin{array}{l}\text { Guo et al., } \\
2003\end{array}$ \\
\hline & $\begin{array}{l}\text { Hongkong, Restaurant } \\
\text { (2001) }\end{array}$ & 16 & $\begin{array}{l}10.3 \pm 5.5 \\
(3.7-18.3)\end{array}$ & $\begin{array}{l}85.8 \pm 49.5 \\
(17.6-152.2)\end{array}$ & $\begin{array}{l}8.6 \pm 5.7 \\
(3.0-17.4)\end{array}$ & $\begin{array}{l}10.9 \pm 8.8 \\
(2.1-24.6)\end{array}$ & $\begin{array}{l}5.9 \pm 7.1 \\
(0-18.5)\end{array}$ & $\begin{array}{l}\text { Guo et al., } \\
2003\end{array}$ \\
\hline & $\begin{array}{l}\text { Hangzhou } \\
(5 / 2002,10,11 / 2003)\end{array}$ & 31 & 4.899 & 21.37 & 15.10 & 19.96 & 9.76 & $\begin{array}{l}\text { Zhong et al., } \\
2005\end{array}$ \\
\hline \multirow[t]{8}{*}{ Outdoor } & $\begin{array}{l}\text { Dongbaituo, Hebei } \\
(1 / 2013)\end{array}$ & 49 & $\begin{array}{l}27.2 \pm 16.0 \\
(6.6-68.9)\end{array}$ & $\begin{array}{l}29.3 \pm 14.6 \\
(6.4-80.1)\end{array}$ & $\begin{array}{l}12.0 \pm 6.8 \\
(4.8-41.3)\end{array}$ & $\begin{array}{l}18.0 \pm 9.6 \\
{[6.1-45.8]}\end{array}$ & $\begin{array}{c}15.7 \pm 10.4 \\
(1.9-53.3)\end{array}$ & This work \\
\hline & Beijing (Winter, 2008) & 190 & $\begin{array}{l}6.9 \pm 6.7 \\
(0.9-24.1)\end{array}$ & $\begin{array}{l}10.4 \pm 10.6 \\
(0.8-41.0)\end{array}$ & $\begin{array}{l}2.5 \pm 2.5 \\
(0.2-11.9)\end{array}$ & $\begin{array}{l}4.9 \pm 4.4 \\
(0.4-21.9)\end{array}$ & $\begin{array}{l}2.2 \pm 2.0 \\
(0.2-9.9)\end{array}$ & $\begin{array}{l}\text { Zhang et al., } \\
2012\end{array}$ \\
\hline & Beijing (Winter, 2009) & 140 & $\begin{array}{l}9.2 \pm 7.6 \\
(0.8-31.2)\end{array}$ & $\begin{array}{l}14.5 \pm 13.2 \\
(1.2-58.7)\end{array}$ & $\begin{array}{l}4.4 \pm 4.5 \\
(0.3-18.2)\end{array}$ & $\begin{array}{l}7.5 \pm 7.1 \\
(0.6-34.1)\end{array}$ & $\begin{array}{l}3.5 \pm 3.2 \\
(0.3-14.8)\end{array}$ & $\begin{array}{l}\text { Zhang et al., } \\
2012\end{array}$ \\
\hline & Beijing (8-9/2012) & 43 & $1.7(0.2-5.1)$ & $5.4(0.4-22.3)$ & $1.2(0.1-5.8)$ & $2.1[0.1-10.5]$ & $0.5(0.1-2.6)$ & Li et al., 2014 \\
\hline & $\begin{array}{l}\text { Pearl River Delta, } \\
(10-12 / 2007)\end{array}$ & 102 & $2.5(0.7-9.3)$ & $18.0(0.4-116.1)$ & $6.2(0.2-119.5)$ & $9.5(0.3-365.5)$ & $3.5(0.1-115.9)$ & $\begin{array}{l}\text { Ling et al., } \\
2011\end{array}$ \\
\hline & Guangzhou $(7,11 / 2002)$ & 169 & $8.9 \pm 11.5$ & $40.3 \pm 56.8$ & $7.3 \pm 12.5$ & $6.2 \pm 12.3$ & $4.6 \pm 11.6$ & $\begin{array}{l}\text { Wang et al., } \\
2008\end{array}$ \\
\hline & $\begin{array}{l}\text { Nanjing (4/2006- } \\
1 / 2007)\end{array}$ & 430 & $6.4 \pm 3.8$ & $19.8 \pm 10.3$ & $2.9 \pm 2.1$ & $3.4 \pm 2.8$ & $2.1 \pm 2.2$ & $\begin{array}{l}\text { Wang and } \\
\text { Zhao, } 2008\end{array}$ \\
\hline & $\begin{array}{l}\text { TaiO, Hongkong } \\
(10-12 / 2001,2012)\end{array}$ & 32 & $\begin{array}{l}3.0 \pm 3.2 \\
(0.1-35.9)\end{array}$ & $\begin{array}{l}23.3 \pm 29.3 \\
(0.1-201.2)\end{array}$ & $\begin{array}{c}4.0 \pm 5.8 \\
(-38.4)\end{array}$ & $\begin{array}{c}4.6 \pm 8.8 \\
(-69.7)\end{array}$ & $\begin{array}{l}1.8 \pm 2.7 \\
(-20.5)\end{array}$ & $\begin{array}{l}\text { Guo et al., } \\
2006\end{array}$ \\
\hline
\end{tabular}

2005; Liu et al., 2009), and values $\geq 1$ have been reported for biofuel, charcoal burning and coal burning (Moreira dos Santos et al., 2004). The $\mathrm{B} / \mathrm{T}$ ratios of $1.17 \pm 0.34$ in this work strongly suggested that coal burning was the main source in the rural area.

\subsection{Health risk assessment}

In order to evaluate the threat to the local inhabitants' health caused by BTEX, the non-cancer hazard (Hazard Quotient, $\mathrm{HQ}$ ) and life cycle cancer risk (CR) due to the exposure to BTEX were roughly estimated (listed in Table 2) based on the data investigated in this work and the health risk assessment method proposed by US EPA (see: rais.ornl.gov). Here, the exposure concentration $\left(E C, \mu \mathrm{g} / \mathrm{m}^{3}\right.$ ) was calculated from Eq. (1):

$$
\mathrm{EC}=\mathrm{CA} \times \mathrm{ET} \times \mathrm{EF} \times \mathrm{ED} / \mathrm{AT}
$$

where, CA $\left(\mathrm{mg} / \mathrm{m}^{3}\right)$ is the concentration of the pollutant, which was derived by averaging the concentrations of BTEX in winter (four months) and other seasons (eight months). The average concentrations obtained by this study were adopted as the concentrations in winter, the concentrations in other seasons

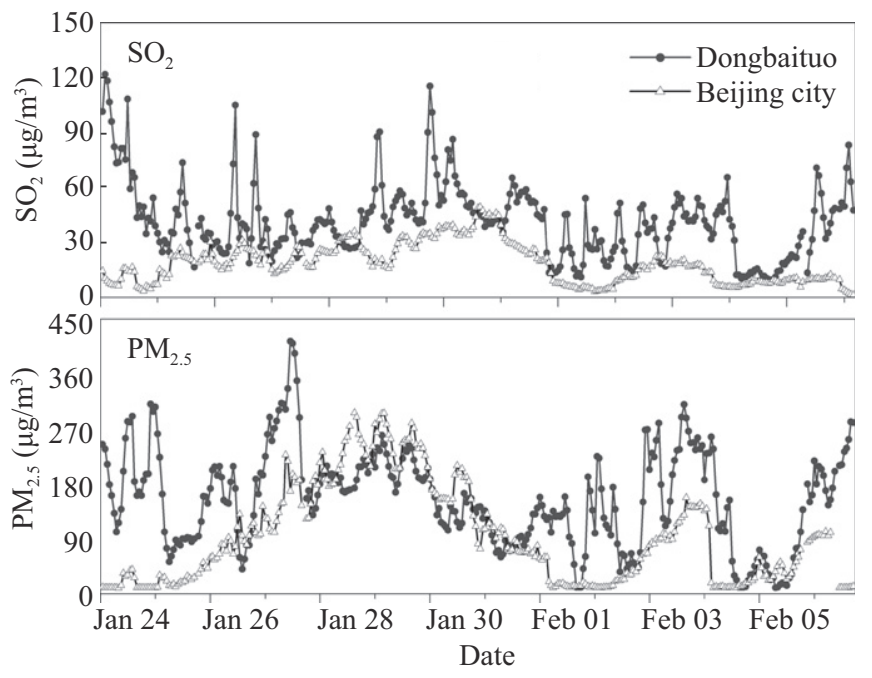

Fig. 2 - Outdoor concentration levels of $\mathrm{PM}_{2.5}$ and $\mathrm{SO}_{2}$ in DBT (Dongbaituo) and Beijing city from 24 January to 6 February, 2013. 


\begin{tabular}{|c|c|c|c|c|c|c|c|c|}
\hline \multirow[t]{2}{*}{ BTEX } & \multicolumn{2}{|c|}{$\mathrm{EC}\left(\mu \mathrm{g} / \mathrm{m}^{3}\right)$} & \multirow{2}{*}{$\frac{\mathrm{RfC}}{\left(\mathrm{mg} / \mathrm{m}^{3}\right)}$} & \multirow{2}{*}{$\frac{\text { IUR }}{\left(\mathrm{m}^{3} / \mu \mathrm{g}\right)}$} & \multicolumn{2}{|c|}{ HQ } & \multicolumn{2}{|c|}{ Risk } \\
\hline & Indoor & Outdoor & & & Indoor & Outdoor & Indoor & Outdoor \\
\hline Benzene & 11.5 & 9.7 & 0.03 & $7.8 \mathrm{E}-06$ & $3.82 \mathrm{E}-01$ & $3.24 \mathrm{E}-01$ & $8.94 \mathrm{E}-05$ & $7.59 \mathrm{E}-05$ \\
\hline Toluene & 19.6 & 9.8 & 5 & & $3.93 \mathrm{E}-03$ & $1.95 \mathrm{E}-03$ & & \\
\hline Ethylbenzene & 9.3 & 4.0 & 1.0 & & $9.33 \mathrm{E}-03$ & $4.00 \mathrm{E}-03$ & & \\
\hline m,p-Xylene & 19.4 & 6.0 & 0.1 & & $1.94 \mathrm{E}-01$ & $6.00 \mathrm{E}-02$ & & \\
\hline o-Xylene & 10.1 & 5.2 & 0.1 & & $1.01 \mathrm{E}-01$ & $5.23 \mathrm{E}-02$ & & \\
\hline
\end{tabular}

were assumed to be $0 \mu \mathrm{g} / \mathrm{m}^{3}$; ET ( $24 \mathrm{hr} /$ day) is the exposure time; EF (365 days/year) is the exposure frequency; ED (70 years) is the exposure duration, and AT $(70 \times 365 \times 24 \mathrm{hr})$ is the averaging time.

The HQ and CR were calculated from Eqs. (2) and (3):

$\mathrm{HQ}=\mathrm{EC} /(\mathrm{RfC} \times 1000)$

$\mathrm{CR}=\mathrm{EC} \times \mathrm{IUR}$

where, RfC $\left(\mathrm{mg} / \mathrm{m}^{3}\right)$ is the reference concentration and IUR $\left(\mathrm{m}^{3} / \mu \mathrm{g}\right)$ is the inhalation unit risk.

According to USEPA document "EPA-540-R-070-002", if the HQ of a specific pollutant is lower than 1, the pollutant has no obvious non-cancer risk to human health, and the acceptable value of cancer risk for an ordinary adult is $1 \mathrm{E}-06$ (Li et al., 2014). The HQ values of 0.38 and 0.32 in this work for indoor and outdoor benzene respectively suggest that benzene poses no obvious non-cancer risk to the farmers in the rural area. However, the cancer risks for both indoor and outdoor benzene greatly exceeded the threshold value of $1 \mathrm{E}-06$, and hence the chronic health effect due to the high concentration of benzene in rural areas of the NCP in winter must be given attention.

\section{Conclusions}

In this study, the atmospheric levels of outdoor and indoor BTEX in a rural area of the NCP were investigated. The extremely high levels of BTEX in the rural area compared with those reported in cities were mainly ascribed to domestic coal combustion for heating during the winter season. The extremely high values of Hazard Quotient and cancer Risks for both the indoor and outdoor benzene indicated that the high pollution levels of benzene in the rural area of the NCP were threatening the farmers' health, and hence effective control measures are urgently needed to improve the air quality in rural areas of the NCP during the winter season.

\section{Acknowledgments}

This work was supported by the Strategic Priority Research Program of the Chinese Academy of Sciences (No. XDB05010100), the National Basic Research and the Development Program 973 (No. 2010CB732304), the National Natural Science Foundation of China (No. 21177140, 41203070), and the China Postdoctoral Science Foundation (No. 2012M520404).

\section{R E F E R E N C E S}

Aksoy, M., 1989. Hematotoxicity and carcinogenicity of benzene. Environ. Health Perspect. 82, 193-197.

Barletta, B., Meinardi, S., Rowland, S.F., Chan, C.Y., Wang, X.M., Zou, S.C., et al., 2005. Volatile organic compounds in 43 Chinese cities. Atmos. Environ. 39 (32), 5979-5990.

Barletta, B., Meinardi, S., Simpson, I.J., Zou, S., Rowland, S.F., Blake, D.R., 2008. Ambient mixing ratios of nonmethane hydrocarbons (NMHCs) in two major urban centers of the Pearl River Delta (PRD) region: Guangzhou and Dongguan. Atmos. Environ. 42 (18), 4393-4408.

Brocco, D., Fratarcangeli, R., Lepore, L., Petricca, M., Ventrone, I., 1997. Determination of aromatic hydrocarbons in urban air of Rome. Atmos. Environ. 31 (4), 557-566.

Buczynska, A.J., Krata, A., Stranger, M., Godoi, A.F., KontozovaDeutsch, V., Bencs, L., et al., 2009. Atmospheric BTEXconcentrations in an area with intensive street traffic. Atmos. Environ. 43 (2), 31-318.

Dutta, C., Som, D., Chatterjee, A., Mukherjee, A.K., Jana, T.K., Sen, S., 2009. Mixing ratios of carbonyls and BTEX in ambient air of Kolkata, India and their associated health risk. Environ. Monit. Assess. 148 (1-4), 97-107.

Guo, H., Lee, S.C., Li, W.M., Cao, J.J., 2003. Source characterization of BTEX in indoor microenvironments in Hong Kong. Atmos. Environ. 37 (1), 73-82.

Guo, H., Wang, T., Blake, D.R., Simpson, I.J., Kwok, Y.H., Li, Y.S., 2006. Regional and local contributions to ambient nonmethane volatile organic compounds at a polluted rural/ coastal site in Pearl River Delta. China Atmos. Environ. 40 (13), 2345-2359.

Li, L., Li, H., Zhang, X.M., Wang, L., Xu, L.H., Wang, X.Z., et al., 2014. Pollution characteristics and health risk assessment of benzene homologues in ambient air in the northeastern urban area of Beijing, China. J. Environ. Sci. 26 (1), 214-223.

Ling, Z.H., Guo, H., Cheng, H.R., Yu, Y.F., 2011. Sources of ambient volatile organic compounds and their contributions to photochemical ozone formation at a site in the Pearl River Delta, southern China. Environ. Pollut. 159 (10), 2310-2319.

Liu, J.F., Mu, Y.J., Zhang, Y.J., Zhang, Z.M., Wang, X.K., Liu, Y., et al., 2009. Atmospheric levels of BTEX compounds during the 2008 Olympic Games in the urban area of Beijing. Sci. Total Environ. 408 (1), 109-116.

Liu, K.K., Quan, J.N., Mu, Y.J., Zhang, Q., Liu, J.F., Gao, Y., et al., 2013. Aircraft measurements of BTEX compounds around Beijing city. Atmos. Environ. 73, 11-15.

Moreira dos Santos, C.Y., de Almeida Azevedo, D., de Aquino Neto, F.R., 2004. Atmospheric distribution of organic compounds from urban areas near a coal-fired power station. Atmos. Environ. 38 (9), 1247-1257.

Perry, R., Gee, I.L., 1995. Vehicle emissions in relation to fuel composition. Sci. Total Environ. 169 (1-3), 149-156.

Quan, J.N., Gao, Y., Zhang, Q., Tie, X.X., Cao, J.J., Han, S.Q., et al., 2013. Evolution of planetary boundary layer under different 
weather conditions, and its impact on aerosol concentrations. Particuology 11 (1), 34-40.

Wang, P., Zhao, W., 2008. Assessment of ambient volatile organic compounds (VOCs) near major roads in urban Nanjing. China Atmos. Res. 89 (3), 289-297.

Wang, B.G., Zhang, Y.H., Shao, M., Zhou, Y., Feng, Z.C., 2008. Sources apportionment of anthropogenic C2-C9 non-methane hydrocarbons in the atmosphere of Guangzhou, China. Acta Sci. Circumst. 28 (7), 1430-1440.

Wang, Y.S., Ren, X.Y., Ji, D.S., Zhang, J.Q., Sun, J., Wu, F., 2012. Characterization of volatile organic compounds in the urban area of Beijing from 2000 to 2007. J. Environ. Sci. 24 (1), 95-101.

Yuan, B., Shao, M., Lu, S.H., Wang, B., 2010. Source profiles of volatile organic compounds associated with solvent use in Beijing. China Atmos. Environ. 44 (15), 1919-1926.

Zhang, Y.J., Mu, Y.J., Liu, J.F., Mellouki, A., 2012. Levels, sources and health risks of carbonyls and BTEX in the ambient air of Beijing, China. J. Environ. Sci. 24 (1), 124-130.

Zhong, T.X., Liu, S.F., Tian, J., 2005. Source apportionment and pollution survey of aromatic compounds in indoor air of Hangzhou. Environ. Monit. China 21 (6), 66-70. 